\title{
DETECTION OF Macrobrachium rosenbergii Nodavirus (MrNV) AND EXTRA SMALL VIRUS (XSV) DISEASES ON GIANT FRESHWATER PRAWN, Macrobrachium rosenbergii AT SAMAS, YOGYAKARTA
}

\author{
Isti Koesharyani" and Lila Gardenia \\ Center for Aquaculture Research and Development, J akarta
}

(Received 29 December 2013; Accepted 25 April 2014)

\begin{abstract}
Mass mortality of giant freshwater prawn (Macrobrachium rosenbergii de Man) in grow- out farmers occurred in early February 2012 at Instalation Coastal of Aquaculture Samas, Bantul, D.I. Yogyakarta. The clinical sign of shrimp was whitish coloration on abdominal and tail muscle. The sympton was the same as in other cases of mortality caused by prawn Macrobrachium rosenbergii nodavirus (MrNV) and Extra Small Virus (XSV). Prawn samples were diagnosed by standard protocols Reverse TranscriptasePolymerase Chain Reaction (RT-PCR) using specific primers and histopathology analysis. The result showed that all samples indicated positive 13/15 the MrNV and 5/ 15 positive XSV, and there were 4/ 15 positive samples both (MrNV and XSV). Analysis of histopathology showed that damaged muscle was indicated by the presentation of necrotic tissues with nuclear pyknosis or degeneration of muscle in infected tissues. Based on diagnosis by RT-PCR and histopathological, mass mortality of the giant freshwater prawn in Indonesia is determined to be caused by "white muscle disease (WMD)/ white tail disease (WTD)".
\end{abstract}

KEYWORDS: freshwater prawn, Macrobrachium rosenbergii nodavirus (MrNV) and Extra Small Virus (XSV), RT- PCR, histopathology

\section{INTRODUCTION}

The giant freshwater prawn (Macrobrachium rosenbergii) is an economically potential commodity due to its good market share. Prawn farming techniques have been developed and performed by farmers and entrepreneurs widely. However, along with the development of good farming techniques there have been always problems of emerging disease. Some diseases could be caused by protozoa such as Epistylis sp., Zoothamium sp., and Vorticela sp., while bacterial diseases could be caused by Aeromonas sp., Psedomonas sp., Enterobacter sp., and Vibrio sp. Others such as black spot disease, black gills disease, and Idiopathic muscle necrosis (IMN) or white muscle disease, and another disease caused by fungus such as Fusarium sp. These kinds of diseases have been reported to be infecting prawn farming especially in larval stadia (Supriyadi et al., 2001). But viral infectious disease is a major constraint in prawn farming and could cause high mortality and economic losses as in the case of White Spot Syndrome Virus (WSSV) infection in tiger prawn (Penaeus monodon) and whiteleg prawn (Litopenaeus vannamei).

Viral infections in prawns have not been widely identified scientifically in Indonesia. Viral diseases could occur at any time and

\# Corresponding author. Center for Aquaculture Research and Development Jl. Ragunan 20, Pasar Minggu, Jakarta Selatan 12540, Indonesia. Phone: +62 217805052

E-mail: istisugama@yahoo.com 
could be caused by environment changes, high intensive system of prawn farming or free trading causing unproperly applied quarantine rules which made some new diseases can spread easily. A new viral disease which caused $30 \% 40 \%$ mortality of giant freshwater have occurred in early 2012 at Samas Yogyakarta. The major symptom of infected prawns are whitening muscle in the tail and abdominal, or known as White Tail Disease (WTD).

According to several reports, the WTD is caused by Macrobrachium rosenbergii nodavirus (MrNV) or Extra Small Virus (XSV). The virus has been known could infect the prawn both at post- larva (PL) and adult stage (Arcier et al., 1999; Qian et al., 2003; Widada et al., 2003; Hameed et al., 2004a; Hsieh et al., 2006; Yonganandhan et al., 2006; Wang et al., 2008). Detection of WTD could be conducted by several methods such as histology and electron microscope. Sandwich enzyme linked immunosorbent assay methods (S- ELISA) based on antigen- antibody interaction (Romestand \& Bonami, 2003). Genome- based detection by dot- blot technique, in situ hybridization and Reverse Transcriptase Polymerase Chain Reaction/ RT- PCR (Widada et al., 2003; Hameed et al., 2004a; Shekhar et al., 2006; Yonganandhan et al., 2006; Hsieh et al., 2006; Behera et al., 2011). Detection with loop- mediated isothermal amplification method or LAMP has been known (Pillai et al., 2006). Now there is XSV specific detection based on genome analysis (Widada et al., 2004). Simultaneous detection in one tube for WTD (MrNV- XSV) has also been tried (Yonganandhan et al., 2005; Tripathy et al., 2006). Qualitative detection could be conducted by using Tagman probe for Real Time or Quantitative Polymerase Chain Reaction (qPCR) (Zhang et al., 2006).

Based on all informations and studies of WTD, the purpose of this research is to confirm the diagnosis on the mortality of giant freshwater prawn with WTD symptoms at Instalation Coastal of Aquaculture Samas-Bantul D.I. Yogyakarta by using histopathology and RTPCR method.

\section{MATERIALS AND METHODS}

Samples of infected giant freshwater prawn (pleopod, muscle, tail, and gills) were taken in the middle of February 2012 from Instalation Coastal of Aquaculture Samas, Bantul, D.I. Yogyakarta and were kept in RNA later solu- tion. Meanwhile, the whole specimen of giant freshwater prawn were kept in Davidson's solution for 24 hours before being transfered to $70 \%$ Ethanol for histophatology analysis. All the samples were recorded for RT- PCR analysis in Fish Health Laboratory at the Center Research for Aquaculture in Jakarta, while histopathology analysis was conducted in Tuscon Arizona USA.

\section{RNA Extraction}

Extraction of total RNA was conducted by using TRI Reagent Kit. Tissue samples of 50$100 \mathrm{mg}$ were placed on $1.5 \mathrm{~mL}$ sterile microtube. Those samples were air-dried before added $1 \mathrm{~mL}$ of lysis solution. Samples were incubated at room temperature $\left(25^{\circ} \mathrm{C}\right)$ for $5 \mathrm{~min}$ utes, then centrifuged (High Speed Refrigerated Micro Centrifuge XT- 160) at 12,000 rpm for 10 minutes at $4^{\circ} \mathrm{C}$. Supernatant was transferred to a new microtube and added $200 \mathrm{~mL}$ Chloroform, then recentrifuged at $12,000 \mathrm{rpm}$ for 10 minutes at $4^{\circ} \mathrm{C}$. The clear part (aqueous phase) was then transferred to a new microtube. Furthermore, a total of $500 \mathrm{~mL}$ Isopropanol was added into the tubes and then vortexed for 5 - 10 seconds before being incubated at room temperature for 5- 10 minutes. The suspensions were centrifuged at 12,000 rpm for 10 minutes at $4^{\circ} \mathrm{C}$ and supernatant were discarded, then $75 \%$ ethanol was added to wash the RNA pellet before being centrifuged again at 7,500 rpm for 5 minutes at $4^{\circ} \mathrm{C}$. Ethanol was removed and the pellet was airdried. The pellet was resuspended by 100- 200 $\mathrm{mL} \mathrm{ddH_{2 }} \mathrm{O}$ addition then the density was measured by NanoDrop. Result of the measurements ranges between $142-825 \mathrm{ng} / \mu \mathrm{L}$ with purity level of $1.83-1.95$ at $260 / 280 \mathrm{~nm}$ wavelength. RNA was then diluted up to 100- 200 $\mathrm{ng} / \mu \mathrm{L}$ before amplification process.

\section{Reverse Transcriptase- Polymerase Chain Reaction}

Moleculer analysis was used to detect the existence of WTD caused by MrNV and XSV on infected samples, RNA- 2 specific primer for MrNV have 425 bp of target molecular weight (Hameed et al., 2004a), while XS1/XS5 specific primer for XSV have 500 bp of target molecular weight (Widada et al., 2004). The sequence of specific primer is shown in Table 1.

AccessQuick Master Mix was used to amplify or reproduce DNA/c- DNA targets. AccessQuick Promega 2x Master Mix (TfI DNA poly- 
Detection of Macrobrachium rosenbergii Nodavirus (MrNV) ... (Isti Koesharyani)

Table 1. The specific primers used to detect WTD (MrNV and XSV) of giant freshwater prawn infected samples

\begin{tabular}{ccccc}
\hline Pair & Name & Size (bp) & Primers sequences 5' 3' & Reference \\
\hline \multirow{2}{*}{ RNA-2 } & $\begin{array}{c}\text { Mr NV2aF } \\
\text { Mr NV2aR }\end{array}$ & 425 & $\begin{array}{c}\text { gCg TTA TAg Atg gCA CAA gg } \\
\text { AgC TgT gAA ACT TCC ACT gg }\end{array}$ & $\begin{array}{c}\text { Hameed et al. (2004a) } \\
\text { Gen Bank AY222840 }\end{array}$ \\
\hline XS1/ XS5 & $\begin{array}{c}\text { XS1-R } \\
\text { XS5-F }\end{array}$ & 500 & $\begin{array}{c}\text { ggA gAA CCA TgA gAT CAC g } \\
\text { CTg CTC ATT ACT gTT Cgg AgT C }\end{array}$ & $\begin{array}{c}\text { Widada et al. (2004) } \\
\text { Gen Bank AY247793 }\end{array}$ \\
\hline
\end{tabular}

merase, dNTPs, magnesium sulfate, and reaction buffer) and AMV RT was added separately to each reaction. Amplification reaction of total $20 \mathrm{~mL}$, each used $1 \mathrm{~mL}$ Reverse and forward primer (18 pmol). RT- PCR was performed in RT cycling conditions of $52^{\circ} \mathrm{C}$ for $30 \mathrm{~min}$ utes and $95^{\circ} \mathrm{C}$ for 2 minutes (to convert RNA to c- DNA), followed by 30 cycles at $94^{\circ} \mathrm{C}$ for 40 seconds, $55^{\circ} \mathrm{C}$ for 40 seconds, $68^{\circ} \mathrm{C}$ for 60 seconds and at $68^{\circ} \mathrm{C}$ for 10 minutes. Analysis of RT- PCR products on a 1.5\%gel electrophoresis in 1x TAE buffer and stained with ethidium bromide, the target product was measured using a 100 bp DNA ladder/ marker under UVTransilluminator.

\section{Histopathology Analysis}

Infected tissue organ (muscle) were fixed in Davidson's solution for 24 hours then transferred for refixation process in $70 \%$ ethanol solution for futher histopathologycal analysis. Naturally infected tissue samples of giant freshwater prawn were analyzed at the Department of Veterinary Science and Microbiology The University of Arizona, Tuscon, AZ, USA with case No. 12- 152, 12 August 2012.
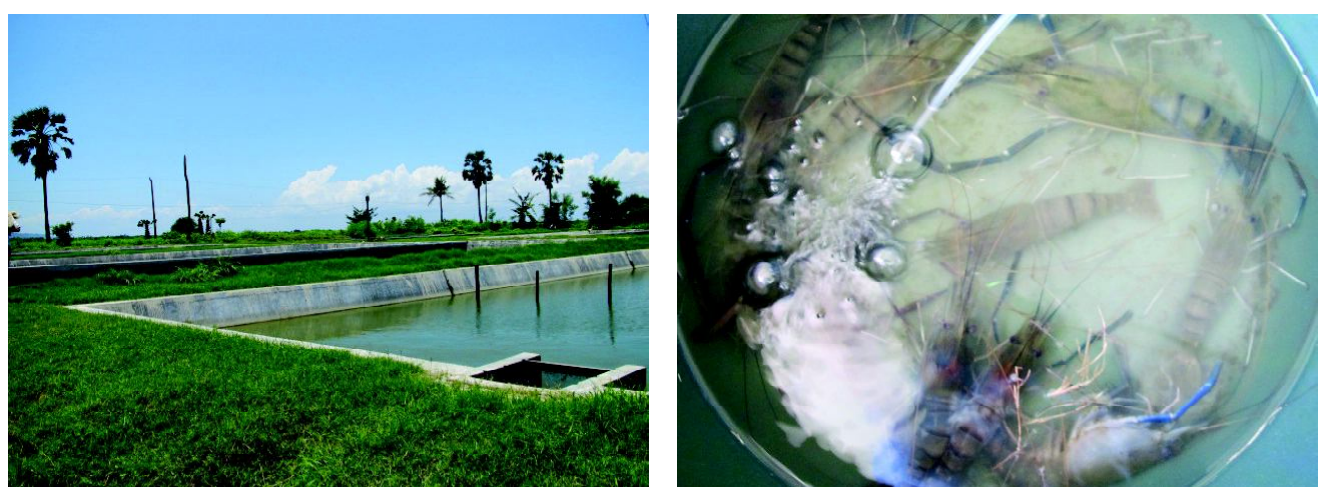

Figure 1. Conditions prawn ponds and infected giant freshwater prawn at Instalation Coastal of Aquaculture Samas, Bantul, D.I. Yogyakarta

\section{RESULT AND DISCUSSION}

The mortality of giant freshwater prawn broodstock strain G- macro and Synthetic, was found in Instalation Coastal of Aquaculture Samas, Bantul, D.I. Yogyakarta in February 2012. Prawn were cultured using traditional farming systems in concrete ponds in area of $250 \mathrm{~m}^{2}$ with density of 3- $5 \mathrm{seed} / \mathrm{m}^{2}$. Post- larvae source cames from Sukamandi, West Java. Mortality occurred after the prawn was kept for 2.5 months, and mortality rate reached $30 \% 40 \%$ (Figure 1).

The symptom is whitish discoloration and opacity of the abdominal and tail muscles of the prawn which is known as White Tail Disease or WTD (Figures 2a and 2b). According to the farmers, clinical symptom of infected prawns has existed for sometime, but there is no definitive explanation of the cause. The symptom is similar to giant freshwater prawn mortality cases found in France, India, Thailand, and China, which is caused by MrNV and XSV (Arcier et al., 1999; Widada et al., 2003; Hameed et al., 2004a; Hsieh et al., 2006; Yoganandhan et al., 2006; Wang et al., 2008). 

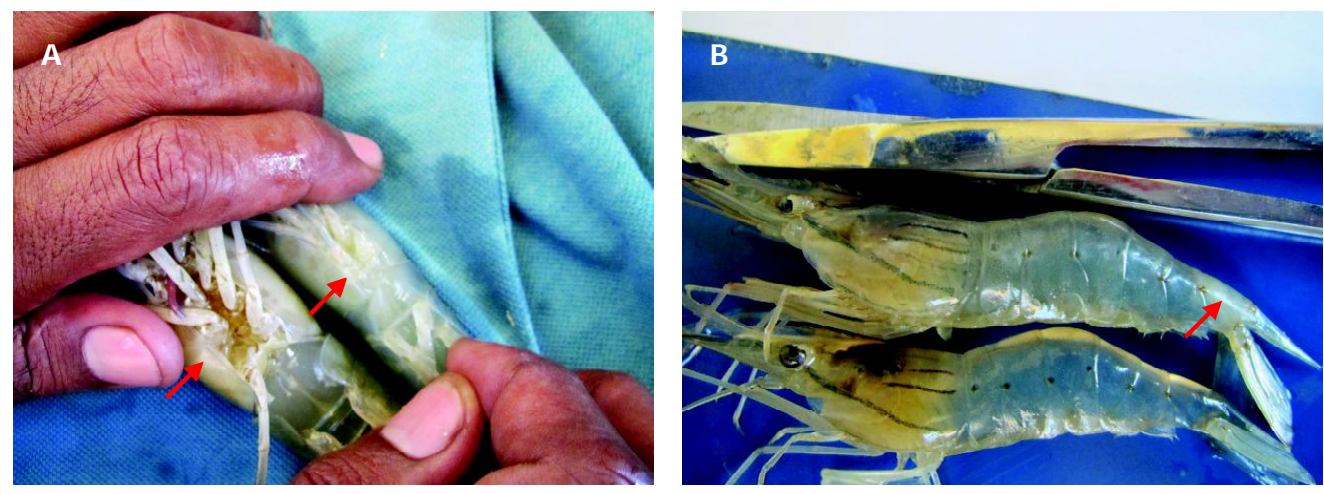

Figure 2. Gross signs of giant freshwater prawn infected with MrNV, showing whitish discoloration and opacity of the abdominal (A) and (B) tail muscles (arrows) in Instalation Coastal of Aquaculture Samas, Bantul, D.I. Yogyakarta

According to Arcier et al. (1999), the case of WTD at post- larvae (PL) stage, the whitish coloration is hardly visible. Mortality will occur 5 days after the sight of early symptom or the existence of whitish coloration on its body.

The RT-PCR amplification with specific primer MrNV and XSV (Hameed et al., 2004a; Widada et al., 2003), has shown that there is an indication of WTD symptom on tissue samples of infected giant freshwater prawn which undergo mass mortality. Out of 15 samples (13/ 15) are positive MrNV. Meanwhile, for XSV diagnosis, 5 out of 15 samples are infected with XSV. Furthermore, there are 4 samples (4/ 15) which are positively infected by both MrNV and XSV (Table 2).

Almost at the same periode of time, mortality also found in other area such as Sukamandi, Pangandaran, and Sukabumi with WTD symptom but with lower rate of mortality. It seems that the cause of mortality is the same (data is not shown). It has been known for quite some time that WTD is the main obstacle on giant freshwater prawn farming on hatchery or grow up ponds. This is similar with WSSV infection case on Tiger prawn farming, which has not been resolved until this time. WTD was firstly identified in the hatchery of giant freshwater prawn at Pointe Noire, France. For periods of 10 years (1985-1994) those hatchery undergo mass mortality up to $5 \% 90 \%$ cumulative mortality.

RT- PCR diagnosis could be seen from the amplification result on gel electrophoresis, where each type of virus was shown in different target of molecular weight. The samples
Table 2. Diagnostic amplification RT-PCR MrNV and XSV results of natural infection freshwater prawn from Instalation Coastal of Aquaculture Samas, Bantul, D.I. Yogyakarta

\begin{tabular}{cll}
\hline \multirow{2}{*}{$\begin{array}{c}\text { Samples } \\
\text { freshwater } \\
\text { praw n }\end{array}$} & \multicolumn{2}{c}{ Viruses detection } \\
\cline { 2 - 3 } & Mr NV & \multicolumn{1}{c}{ XSV } \\
\hline 1 & Positive & Positive \\
2 & Positive & Negative \\
3 & Positive & Negative \\
4 & Positive & Negative \\
5 & Positive & Negative \\
6 & Positive & Negative \\
7 & Positive & Negative \\
8 & Positive & Negative \\
9 & Positive & Negative \\
10 & Positive & Positive \\
11 & Negative & Positive \\
12 & Positive & Positive \\
13 & Positive & Negative \\
14 & Positive & Positive \\
15 & Negative & Negative \\
\hline
\end{tabular}

with 425 bp molecular weight means positive result for MrNV and 500 bp for XSV (Figure 3).

Both types of primer are chosen due to its sensitivity level especially for MrNV primer that could detect up to smallest concentration of $0.25 \mathrm{fg}$, while the XSV primer could detect on the level of $25 \mathrm{fg}$ (Hammed et al., 2004a). WTD cases caused by MrNV and XSV are commonly 
Detection of Macrobrachium rosenbergii Nodavirus (MrNV) ... (Isti Koesharyani)

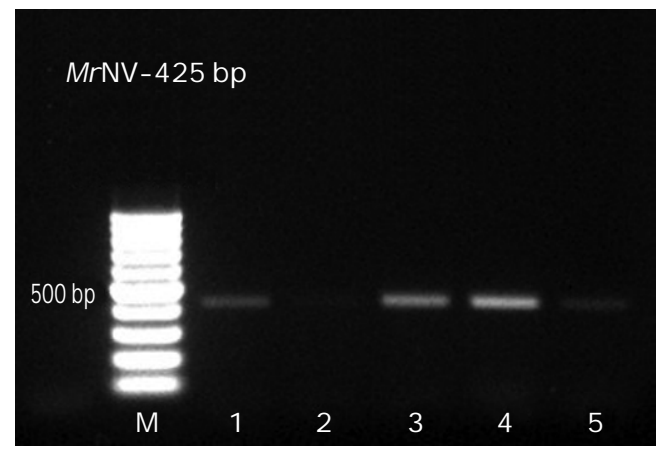

Macrobrachium rosenbergii NodaVirus (425 bp)

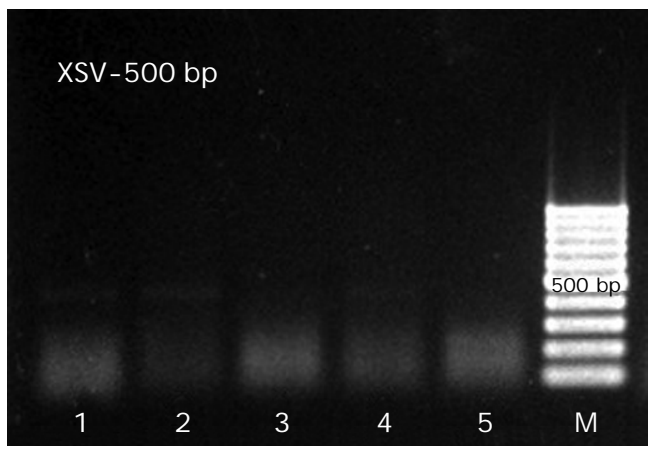

Extra Small Virus (500 bp)

Figure 3. Amplification product of MrNV and XSV RT- PCR, in natural infection of giant freshwater prawn from Instalation Coastal of Aquaculture Samas, Bantul, D.I. Yogyakarta, 1- $5=$ samples, $\mathrm{M}=$ DNA ladder of $100 \mathrm{bp}$

found concurrently on mortality case of giant freshwater prawn. But, on specific case, WTD could also become the cause of XSV or MrNV infection only, which is the case of Samas, Yogyakarta. This is still under research to find out the role of each cause of WTD.

There are studies on the role of XSV on WTD case, which remains unclear up to now. There are 3 hypothesis on the role of XSV: first, XSV is not a virus developing in giant freshwater prawn but infecting the prawn food such as Artemia, though the attemp to extract XSV directly from Artemia were unsuccessful. Second, XSV is an autonomous virus of giant freshwater prawn and third, XSV could be a helper virus for MrNV. Since XSV is always found assosiated with the larger virus (nodavirus) and located in muscle and connective cell of infected prawns, it could be an autonomous virus, a helper-type virus, or satellite- like virus (Qian et al., 2003; Yonganandhan et al., 2006).

MrNV and XSV have been found to be able to infect seawater prawn (Penaeus monodon and $P$. indicus) at post larvae stage in hatchery, where the symptoms are the same with the one infecting giant freshwater prawn and generated positive result by amplification using RT- PCR analysis (Ravi et al., 2009). More than that, Artemia as the prawn natural food could also be infected with MrNV and XSV. Artificial infection by oral administration to the prawn, can cause $100 \%$ mortality (Sudhakaran et al., 2006).

Histopathology analysis of mass mortality in Samas, Yogyakarta can be seen from photomicrographs of infected muscle tissues. Dam- aged muscle was indicated by the presentation of necrotic tissues with nuclear pyknosis or degeneration of muscle in infected tissues (Figure 4B), as a comparison (Figure 4A) is normal muscle tissue of giant freshwater prawn and other changes were hemocytic infiltration at gill infected tissue (Figure 4C) and inclusion bodies- haemocytic infiltration in hepatopancreas (Figure 4D). The description of damaging tissue is similar with the case in Taiwan such as the present of inclusion bodies in infected muscle tissue (Arcier et al., 1999; Hsieh et al., 2006).

On the use of artificial infection, MrNV and XSV could infect the whole organ of the prawn (Post- larvae stage, gill, head muscle, stomach, intestine, heart, hemolymph, pleopod, ovaries, and tail muscle), but the virus was not found in hepatopancreas and eyestalk (Hameed et al., 2004b).

In observation with Transmition Electron Microscope (TEM), it can be seen that morphologically MrNV is a very small particle virus with the shape of icosahedral - non enveloped size in 25- $30 \mathrm{~nm}$ which is located in the cytoplasm of connective tissues at all organs (Arcier et al., 1999; Romestand \& Bonami, 2003; Qian et al., 2003). The shape and diameter size of XSV is smaller (between 14- $16 \mathrm{~nm}$ ), could be identified using TEM and it is usually mixed with the MrNV (Qian et al., 2003).

This is the first report of White Tail Disease caused by MrNV and XSV in Indonesia. Earlier, MrNV, and XSV has been found in several countries with giant freshwater prawn farming such as India (Widada et al., 2003; Hameed et al., 

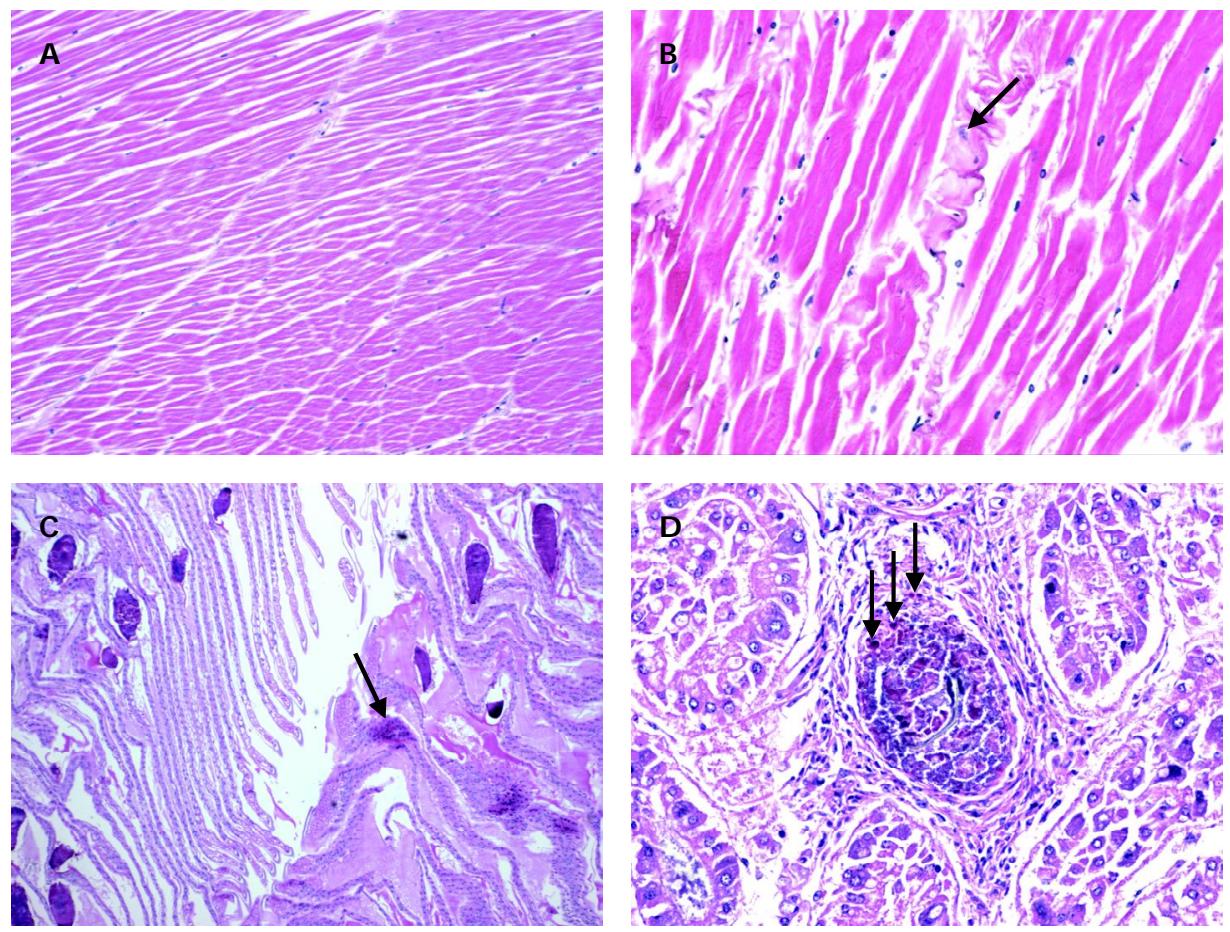

Figure 4. Photomicrograph- histopatology of organ and muscle from giant freshwater prawn infected with WTD (A) normal muscle tissue; (B) infected muscle tissue with nuclear pyknosis (arrow); (C) gill infected tissue with hemocytic infiltration, and (D) hepatopancreas with inclusion bodies and haemocytic infiltration (arrow)

2004a), Taiwan (Tung et al., 1999, Hsieh et al., 2006; Wang et al., 2008), China (Qian et al., 2003; Zhang et al., 2006), France (Arcier et al., 1999; Bonami et al., 2005), and Thailand (Yonganandhan et al., 2006).

Since this virus infects the ovarium, it is important to look for possible vertical infection from broodstock to its larvae. Hence, it is highly advised to be carefull when starting culture of giant freshwater prawn. It is recommended to use only broodstock which are free from both viruses by using RT- PCR technique. It is advised to use hemolymp or pleopod for non lethal samples since pleopod is the target organ for the detection of both viruses (Hameed et al., 2004b).

\section{CONCLUSION}

WTD was detected in giant freshwater prawn farming at Instalation Coastal of Aquaculture Samas, Bantul, D.I. Yogyakarta by using RT- PCR analysis and hispathology. Analy- sis showed that $13 / 15$ and $5 / 15$ of the samples indicated with positive infection to MrNV and XSV respectively and there are 4/ 15 (four) positive samples both (MrNV and XSV). It is important to do selection of giant freshwater prawn broodstock or post- larvae which are free of MrNV and XSV. And also it is needed to do sequencing of nucleotide to identify Mr NV and XSV and compared it with data in Gene- bank.

\section{ACKNOWLEDGEMENTS}

We thank Johan Afandi and Setiadi, the technician at Fish Health Laboratory, for their help in RT- PCR diagnosis and analysis. Further thanks is extended to Dr. Sidrotun Naim for her help in providing histopathology analysis which strengthen the cause analysis of prawn's mass mortality at Instalation Coastal of Aquaculture Samas, Bantul, D.I. Yogyakarta.

\section{REFERENCE}

Arcier, J.M., Herman, F., Lightner, D.V., Redman, 
R.M., Mari, J., \& Bonami, J.B. 1999. A viral desease associated with mortalities in hatchery-reared post larvae of the giant freshwater prawn Macrobrachium rosenbergii. Dis. Aquat. Org., 38: 177- 181.

Behera, D.P., Devdas, K., \& Nayak, L. 2011. Reverse transcriptase polymerase chain reaction is a sensitive diagnostic tool for detection of nodavirus infection in Macrobrachium rosenbergii. International Journal of Fisheries and Aquaculture, 3: 191194.

Bonami, J.R., Shi, Z, Qian, D., \& Widada, J.S. 2005. White tail disease of the giant freshwater prawn, Macrobrachium rosenbergii: separation of the associated virions and characterization of MrNV as a new type of nodavirus. Journal of Fish Diseases, 28: 23- 31.

Hameed, A.S., Yonganandhan, K., Widada, J.S., \& Bonami, J.R. 2004a. Studies on the occurance of Macrobrachium rosenbergii nodavirus and extra small virus- like particles associated with white tail disease of M. rosenbergii in India by RT- PCR detection. Aquaculture, 238: 127- 133.

Hameed, A.S., Yoganandhan, K., Widada, J., \& Bonami, J.R., 2004b. Experimental transmission and tissue tropism of Macrobrachium rosenbergii nodavirus (MrNV) and extra small virus like- particles in Macrobrachium rosenber gii. Dis. Aquat. Org., 62: 191- 196.

Hsieh, C.Y., Wu, Z.B., Tung, M.C., Tu, C., Lo, S.P., Chang, T.C., Chang, C.D., Chen, S.C., Hsieh, Y.C., \& Tsai, S.S. 2006. In situ hybridization and RT- PCR of Macrobrachium rosenbergii nodavirus in giant freshwater prawn, Macrobrachium rosenbergii (de Man), in Taiwan. Journal of Fish Diseases, 29: 665- 671.

Pillai, D., Bonami, J.R., \&Widada, J.S. 2006. Rapid detection of Macrobrachium rosenbergii nodavirus (MrNV) and extra small virus (XSV), the pathogenic agents of white tail disease of Macrobrachium rosenbergii (de Man) by loop- mediated isothermal amplification. Journal of Fish Diseases, 29: 275283.

Qian, D., Shi, Z, Zhang, S., Cao, Z., Liu, W., Li, L., Xie, Y., Cambournac, I., \& Bonami, J.R. 2003. Extra small virus- like particles (XSV) and nodavirus associated with white muscle disease in the giant freshwater prawn, Macrobrachium rosenbergii. Journal of Fish Disease, 26: 521- 527.

Ravi, M., Basha, A.N., Sarathi, M., Idalia, H.H.R., Widada J.S., Bonami, J.R., \& Hameed, A.S.S.
2009. Studies on the occurrance of white tail disease (WTD) caused by MrNV and XSV in hatchery- reared post larvae of Penaeus indicus and P. monodon. Aquaculture, 292: 117- 120.

Romestand, B. \& Bonami, J.R. 2003. A sandwich enzyme linked immunosorbent assay (SELISA) for detection of MrNV in the giant freshwater prawn Macrobrachium rosenbergii (de Man). Journal of Fish Desease, 26: 71- 75.

Shekhar, M.S., Azad, I.S., \&Jithendran, K.P. 2006. RT- PCR and sequence analysis of Macrobrachium rosenbergii nodavirus: Indian isolate. Aquaculture, 252: 128- 132.

Sudhakaran, R., Yonganandhan, K., Ahmed, V.P.I., \& Hameed, A.S.S. 2006. Artemia as a possible vector for Macrobrachium rosenbergii nodavirus (MrNV) and extra small virus transmision (XSV) to Macrobrachium rosenbergii post- larvae. Dis. Aquat. Org., 70: 161- 166.

Sudhakaran, R., Ahmed, V.P.I., Haribabu, P., Mukherjee, S.C., Widada, J.S., Bonami, J.R., \&Hameed, A.S.S. 2007. Experimental vertical transmission of Macrobrachium rosenbergii nodavirus (MrNV) and extra small virus transmision (XSV) from brooders to progeny in Macrobrachium rosenbergii and Artemia. Journal of Fish Disease, 30: 2735.

Supriyadi, H., Taufik, P., \& Rukyani, A. 2001. Pengelolaan lingkungan budidaya dan kesehatan udang galah (Macrobrachium rosenbergii de Man). Proceeding of Workshop Hasil Penelitian Budidaya Udang Galah. Pusat Riset Perikanan Budidaya. Jakarta, p. 23- 28.

Tripathy, S., Sahoo, P.K., Kumari, J., Mishra, B.K., Sarangi, N., \& Ayyappan, S. 2006. Multiplex RT- PCR detection and sequence comparison of viruses MrNV and XSV associated with white tail disease in Macrobrachium rosenbergii. Aquaculture, 258: 134- 139.

Tung, C.W., Wang, C.S., \& Chen, S.N. 1999. Histological and electron microscopic study on Macrobrachium muscle virus (MMV) infection in the giant freshwater prawn, Macrobrachium rosenber gii (de Man), cultured in Taiwan. Journal of Fish Disease, 22: 1- 5.

Widada, J.S, Durand, S., Cambournac, Qian, D., Shi, Z., Dejonghe, E., Richard, V., \& Bonami, J.R. 2003. Genome- based detection methods of Macrobrachium rosenbergii noda- 
Indonesian Aquaculture Journal Vol. 9 No. 1, 2014

virus, a pathogen of the giant freshwater prawn, Macrobrachium rosenbergii: dotblot, in situ hybridization, and RT- PCR. Journal of Fish Disease, 26: 583-590.

Widada, J.S., Richard, V., Shi, Z., Qian, D., \& Bonami, J.R. 2004. Dot- Blot hybridization and RT- PCR detection of extra small virus (XSV) associated with white tail disease of prawn Macrobrachium rosenbergii. Dis. Aquat. Org., 58: 83- 87.

Wang, C.S., Chang, J.S., Wen, C.M., Shih, H.H., \& Chen, S.N. 2008. Macrobrachium rosenber gii nodavirus infection in $\mathrm{M}$. rosenber gii (de Man) with white tail diseases cultured, in Taiwan. Journal of Fish Diseases, 31: 415422.
Yonganandhan, K., Widada, J.S., Bonami, J.R., \& Hameed, A.S.S. 2005. Simultaneous detection of Macrobrachium rosenbergii nodavirus and extra small virus by single tube, one- step multiplex RT- PCR assay. Journal of Fish Diseases, 28: 65- 69.

Yonganandhan, K., Leartvibhas, M., Sriwongpuk, S., \& Limsumawan, C. 2006. White- tail disease of giant freshwater prawn Macrobrachium rosenbergii in Thailand. Dis. Aquat. Org., 69: 255- 258.

Zhang, H., Wang, J., Yuan, J., Li, L., Zhang, J., Bonami, J.R., \& Shi, Z. 2006. Quantitative relationship of two viruses (MrNV and XSV) in white- tail disease of Macrobrachium rosenbergii. Dis. Aquat. Org., 71: 11- 17. 